\title{
TRADEMARKS AND COMPETITION: THE RECENT HISTORY
}

\author{
DANIEL M. MCCLURE*
}

\section{INTRODUCTION}

In 1979, the Trademark Reporter published an article that I had written in law school that surveyed the intellectual history of intellectual property law, and particularly trademark law, from its earliest inception to the late 1970s. ${ }^{1}$ The article focused on the perceived, age-old conflict between encouraging competition and protecting "monopolistic" property rights in the form of patents, copyrights, and trademarks. The history of trademark law was seen as playing out the tension between protecting entitlements on the one hand and encouraging competition by allowing free access to protected trademarks on the other. In the 1970s, this conflict was most apparent in efforts by the Federal Trade Commission ("FTC") to use antitrust laws to directly attack the use of trademarks as anticompetitive. At another level, this conflict was seen as a reflection of the tension between formalism and legal realism.

This article traces the recent history of trademark law and considers how courts, agencies, and legislatures have struggled to resolve the conflict between protection and access, "property rights" and "free competition," and morality and policy. The recent history of trademark law has shown a trend toward greater protection of trademarks and rejection of most claims that trademarks have anticompetitive effects. In retrospect, the aggressive enforcement actions taken by the FTC in the 1970s represented the high-water mark of the attack on trademarks that utilized the argument that trademarks are inherently anticompetitive. Reflecting a shift in antitrust law generally, trademarks have been relatively immune from antitrust attack since the early 1980s. Under current thinking, the goals of antitrust law and trademark protection are perfectly compatible. This shift in antitrust law parallels judicial developments in substantive trademark law where the pendulum has swung back in favor of protection over access. In the recent era, the expansive judicial protection of trademarks has been undergirded by a general acceptance of the economic theories of the Chicago School that trademark use is in fact pro-competitive. ${ }^{2}$

\footnotetext{
Copyright (C) 1996 by Law and Contemporary Problems

* Partner, Fulbright \& Jaworski L.L.P., Houston.

The author acknowledges the research assistance of Robert A. Curtis in the preparation of this article.

1. Daniel M. McClure, Trademarks and Unfair Competition: A Critical History of Legal Thought, 69 TRADEMARK REP. 305 (1979).

2. See infra notes $48-49,52,57-59$ and accompanying text.
} 
These recent developments represent the surprising convergence of legal realist and formalist approaches in bolstering trademark protection. The ultimate legacy of the 1930s legal realist critique of trademarks as "monopolistic" is the 1990s "law and economics" defense of trademark doctrines as promoting economic efficiency. In the legislative area, the Trademark Law Revision Act of $1988^{3}$ and the Federal Trademark Dilution Act of $1995^{4}$ have broadened trademark rights and suggest a return to the old concept of trademarks as "property rights," a view that echoes formalist legal theory of the nineteenth century.

\section{II}

\section{A Brief History of Trademark Law: The Tension Between TRADEMARK PROTECTION AND COMPETITION}

In my previous 1979 aricle, ${ }^{5}$ I examined the historical development of trademark law in terms of the interplay between the varied principles underlying trademark protection (for example, protecting goodwill, promoting commercial morality, preventing consumer deception) and the policy of promoting free competition through open access to trademarks. Although that tension does not explain everything about the history of trademarks, it serves as a useful paradigm to describe the evolution of trademark legal theory and doctrine. More generally, the history of trademark law may be understood in the context of broader currents in legal philosophy and as reflecting historical changes in legal thought characteristic of other areas of the law.

To briefly summarize that 1979 article, the history of trademark law can be seen as playing out certain tensions or themes between competing or conflicting ideas and theories at all levels of legal analysis. At the most basic level of analysis is the conflict between access and protection. At the level of legal doctrine is a conflict within legal rules such as "likelihood of confusion" and the generic/descriptive/suggestive/arbitrary trademark spectrum. ${ }^{6}$ At the level of legal theory is a conflict between property rights and free competition in the market. Finally, at the level of jurisprudence is a conflict between natural rights and utilitarianism.

In the 200-year history of trademarks, the outcome of these various conflicts or tensions has occurred against the backdrop of broader changes in legal philosophy. Broadly speaking, legal history in the United States has evolved from the formative era to the era of formalism in the late nineteenth century;

3. Pub. L. No. 100-667, 102 Stat. 3935 (codified in scattered sections of 15 U.S.C. (1994)).

4. Pub. L. No. 104-98, 109 Stat. 985 (codified at 15 U.S.C. $\$ \$ 1125$ (c)(1), 1127 (1994)).

5. McClure, supra note 1.

6. Trademark cases traditionally recognize a hierarchy or spectrum of the distinctiveness of trademarks ranging from "generic" (not protected) to "merely descriptive" (not protected) to "suggestive" (protected) to "arbitrary and fanciful" (protected). $1 \mathrm{~J}$. THOMAS MCCARTHY, TRADEMARKS AND UNFAIR COMPETITION \& 11.01[1] (3d ed. 1994); Abercrombie \& Fitch Co. v. Hunting World, Inc., 537 F.2d 4 (2d Cir. 1976). 
to the era of legal realism in the 1930s to the era of "reasoned elaboration" in the years following World War II. In each era, changes can be seen in trademark law reflecting these broader philosophical trends. ${ }^{7}$

In the era of formalism, in the late nineteenth century and early twentieth century, law was reduced to a "science," and legal reasoning was a process of deducing legal rules mechanically from certain broader principles. The language of the law itself became determinative of the outcome of legal reasoning; cases were decided by reasoning deductively from certain principles often embodied in a single idea or word. Treating trademarks as "property rights" became the unifying principle for much legal reasoning in the era of formalism. ${ }^{8}$

As a result of the insights offered by legal realism in the 1930s, much law and legal reasoning took a radically different approach. ${ }^{9}$ Because of the perception that law was not truly a science and that deductive reasoning from basic principles concealed the real reasons for decisions, judicial decisionmaking moved toward a more open and pragmatic consideration of policy issues, empirical facts, and "real world" results. In trademark law, legal realism was reflected in the evolution of a more fact-oriented analysis of "likelihood of confusion" in trademark infringement cases.

The legal realists' attack on formalism in legal thought led directly to an examination of the economic consequences of trademarks. One school of economic thought advanced the view that protection of trademarks supported economic monopolies by allowing brand advertising to create product differentiation that created high barriers to market entry by competitors lacking market power. ${ }^{10}$ These economic theories created judicial uncertainty as to the value of trademarks generally and led to some judicial hostility to expanding trademark protection. This economic theory attack on trademark protection was triggered by a seminal book by economist Edward H. Chamberlin that presented a reasoned case against trademarks as reinforcing monopoly power. ${ }^{11}$

As legal philosophy developed in the 1940s and 1950s, under the rubric of "reasoned elaboration," trademark law took on the appearance of a logical and coherent approach to all issues. ${ }^{12}$ Reasoned elaboration allowed for the consideration of the purposes and policies underlying legal rules (an approach that the legal realists had advocated), but purely subjective decisionmaking was seen as controlled by statutory language and the requirement of judges to articulate their reasoning methodically. Trademark case law became more animated by the policies and principles underlying trademark legal doctrine. ${ }^{13}$ But even this approach concealed more fundamental tensions and underlying

7. McClure, supra note 1 , at $310-35$.

8. Id. at 316-26.

9. Id. at 326 .

10. See infra notes 50-51 and accompanying text.

11. Edward H. Chamberlin, ThE TheORY OF MONOPOlistic Competition (1st ed. 1933); McClure, supra note 1, at 329.

12. McClure, supra note 1 , at $342-45$.

13. Id. at $326-35$. 
ideological approaches than was reflected in written opinions and legal commentary. During this time, trademark doctrine appeared settled and fixed, and judicial discretion was seen as limited by the constraints of the statutory language in the Lanham Act passed in $1946 .{ }^{14}$ But the differences in nearly identical infringement cases and in the application of doctrines such as distinguishing unprotected "descriptive" marks from protected "suggestive" marks, belied more fundamental tensions at work that were not fully explained by established trademark doctrine. ${ }^{15}$

As a result of the social, political, and intellectual upheavals of the 1960s and 1970s, legal doctrine saw a revolution ranging from constitutional law to statutory interpretation to the common law. Spurred by "critical legal studies" in the law schools, legal philosophy entered a more uncertain and occasionally radicalized era. ${ }^{16}$ During this time of upheaval, aggressive actions by antitrust enforcers in a variety of areas reached directly into the heart of trademark law. Trademarks came under renewed attack as inherently "anticompetitive" and as mechanisms for preserving the market power of entrenched economic interests. $^{17}$

The tension between trademark protection and competition reached a breaking point in the 1970 s with the filing of the ReaLemon case. ${ }^{18}$ This FTC enforcement action initially sought compulsory, royalty-free licensing of the trademark "ReaLemon" on the ground that use of the mark was anticompetitive because it allegedly maintained the monopoly position of Borden, Inc., in the concentrated lemon juice market. ${ }^{19}$ Such a frontal assault on trademarks had never been made by any enforcement agency before the 1970s. The antitrust laws are designed to promote and protect competition, and the use of the antitrust laws to directly challenge the validity of trademarks sent shivers through the community of trademark owners. ${ }^{20}$ In 1979, it appeared that the future of trademark protection was in jeopardy or at least that trademark protection might be denied in any instance where trademarks were found to assist in the maintenance of monopoly power by any trademark holder. With that ominous prospect, the 1970 s drew to a close.

14. Act of July 5, 1946, 60 Stat. 427 (codified as amended at 15 U.S.C. $\S \S 1051-1127$ (1994)).

15. See McClure, supra note 1 , at $341,344-45$.

16. See generally RoberTo Unger, THE CRitical Legal STUdies MOVEMENT (1986).

17. McClure, supra note 1 , at 348 .

18. Borden, Inc., 92 F.T.C. $669,669-72$ (1978) (reproducing complaint filed by F.T.C. on July 2 , 1974).

19. McClure, supra note 1 , at $348-53$.

20. See J. Thomas McCarthy, Compulsory Licensing of a Trademark: Remedy or Penalty?, 67 TRADEMARK REP. 197 (1977). 
III

\section{Post-1970s Trademark Developments}

\section{A. Recent Developments in the Trademark/Antitrust Interface}

1. The Aftermath of ReaLemon: A Retreat from Antitrust Attacks on Trademarks. In retrospect, it now appears that the widespread concerns of holders of trademarks in the 1970s that resulted from the vigorous FTC antitrust enforcement actions, were unfounded. ReaLemon did not represent the beginning of a trend, but rather the high-water mark for the attack on trademarks as allegedly "anticompetitive." No similar antitrust claims have since been brought by the FTC or the Department of Justice. Therefore, ReaLemon can now be seen as the furthest advance of a radical and potentially revolutionary attack on trademarks as anticompetitive. Moreover, the FTC attacks on trademarks in the 1970s represented not just the furthest advance of an economic attack on trademarks and advertising generally, but the beginning of a counter-assault led by the Chicago School to create an economic justification for trademarks.

The ReaLemon complaint was filed by the FTC in $1974 .^{21}$ In 1976, the administrative law judge ("ALJ") found that Borden had unlawfully monopolized the processed lemon juice market and ordered Borden to grant a ten-year license of its "ReaLemon" trademark to any competitor virtually royalty-free. ${ }^{22}$ The ALJ recommendation to require royalty-free licensing of a valid trademark as a remedy for monopolization prompted an outcry of criticism from trademark holders and the trademark bar. ${ }^{23}$ What was also unsettling to trademark holders was the ALJ's reasoning for recommending compulsory trademark licensing: "The heart of the monopoly power preserved and maintained by respondent Borden lies in the ReaLemon trademark and its dominant market position. For competition to enter the processed lemon juice industry, the barrier to entry which inheres in the ReaLemon trademark must be eliminated." 24

The ALJ's recommendation in ReaLemon demonstrated the acceptance of the economic theories of economist Edward Chamberlin that strong trademarks supported by persuasive advertising could lead to product differentiation and high barriers to entry that maintain monopoly power. ${ }^{25}$

21. Borden, 92 F.T.C. at 669

22. Id. at 672-778 (reproducing initial decision of Aug. 19, 1976). "In a 'monopolization' case, adequate relief must put an end to the monopoly position, and break up or render impotent the monopoly power found to have been preserved and maintained in violation of law." Id. at $\mathbf{7 7 4}$.

23. McCarthy, supra note 20.

24. Borden, 92 F.T.C. at 774.

25. See generally CHAMBERLIN, supra note 11 . 
The final order of the FTC in 1978, however, stopped short of ordering licensing of the ReaLemon trademark as a remedy but left the door open to such a remedy in an appropriate case. ${ }^{26}$ The FTC's opinion did find that Borden had unlawfully monopolized the processed lemon juice market by selective geographic predatory pricing made possible by promotion of its trademark. ${ }^{27}$ The Commission held the following:

Borden, on the other hand, had the enormous market advantage conferred by the ReaLemon trademark and its magnetic pull on the consumer. ... [O]nly the market power inherent in the ReaLemon trademark enabled Borden to manipulate price differentials and discriminate among customers in different areas to maximize its advantage over other producers. ${ }^{28}$

The FTC's final order continued to meet with criticism from the trademark bar. $^{29}$

The Sixth Circuit subsequently affirmed the decision of the FTC in $1982 . .^{30}$ Although the court affirmed the FTC's finding of a violation of Section 2 of the Sherman Act and Section 5 of the FTC Act, ${ }^{31}$ on the basis of predatory pricing, the court also accepted the FTC's view that promotion of a dominant trademark could be anticompetitive:
A highly successful brand name and product differentiation achieved through extensive advertising over the years, standing alone, does not create a presumption of monopoly power. When a seller possesses an overwhelmingly dominant share of the market, however, and differentiates its product from others through a recognized and extensively advertised brand name, thereby enabling the seller to control prices or unreasonably restrict competition, then monopoly power may be found to exist. . . The evidence indicated ReaLemon's successfully differentiated brand name, extensive advertising and ability to command a premium price also acted to some degree as a barrier to entry into the processed lemon juice market. ${ }^{32}$

The dissenting opinion in the ReaLemon case succinctly summarized the opposing view that mere promotion of a trademark, even by a monopolist, is not an antitrust violation:

Advertising is not a use of monopoly power. Successfully promoting one's product is the epitome of the "business acumen" that Grinnell states is not monopolization. . . . It is not a violation of the antitrust laws for a monopolist to take advantage of a consumer preference at the expense of its competitors."

26. Borden, 92 F.T.C. at $\mathbf{7 7 8 - 8 3 3}$ (final order to cease and desist). In a separate opinion, Commission Chairman Pertschuk favored ordering "some form of trademark relief" because "[t]he power inherent in the ReaLemon trademark, and the price premium it permitted, are the root of Borden's monopoly power." Id. at $809,813$.

27. Id. at $803-05$.

28. Id. at 804 .

29. J. Thomas McCarthy, Trademarks, Antitrust and the Federal Trade Commission, 13 JOHN MARSHALL L. REV. 151 (1979).

30. Borden, Inc. v. FTC, 674 F.2d 498 (6th Cir. 1982), vacated, 461 U.S. 940 (1983).

31. Respectively, 15 U.S.C. $\$ 2$ (1994); id. § 45.

32. Borden, 674 F.2d at 511-12.

33. Id. at 519-20 (Kennedy, J., dissenting). The dissent also attacked the FTC's claim that the strength of the ReaLemon trademark resulted from "spurious" product differentiation. "The primary function of a brand name is to provide consumers an assurance of quality. It is quite rational for consumers to pay extra for ReaLemon to minimize their risk of receiving inferior goods." Id. at 520 
With the change of administrations in 1981, newly appointed Republican commissioners of the FTC took a different view of the ReaLemon case. The new FTC chairman, James C. Miller III, requested the other commissioners to support Borden's request for certiorari and order that the case be remanded to the FTC. ${ }^{34}$ Ultimately, Borden and the FTC reached agreement on a modified order with respect to Borden's pricing practice. ${ }^{35}$ At the request of the parties, the Supreme Court vacated and remanded the Sixth Circuit decision. ${ }^{36}$ Dissenting from the Commission's 3-2 vote to accept the settlement, Commissioner Pertschuk (author of the 1978 order) stated that "this modified order represents for all practical purposes an abandonment of the Commission's role in policing predatory pricing by a monopolist." ${ }^{37}$

The FTC's 1983 statement on the modified order approving settlement of the FTC's ReaLemon case completely repudiated the reasoning of the 1978 final order. The statement on the modified order was particularly critical of the 1978 order's treatment of trademark promotion and product differentiation. The order "apparently viewed product differentiation as something pernicious in and of itself." 38 The statement on the modified order emphasized that product differentiation of established brands "also serve[s] important competitive functions," particularly in reducing "the costs to consumers of becoming informed about a brand's advantages and availability." 39 The FTC concluded the following:

The Commission's [1978] decision did not adequately weigh the competitive advantages of Borden's product differentiation and antitrust laws' promotion of interbrand competition. Instead, it assumed that consumer preference for Borden necessarily constituted an anticompetitive barrier protecting Borden's monopoly position from erosion by new entrants ... . Because the Commission's [1978] analysis of Borden's brand advantage appears to be inconsistent with the purposes of the antitrust laws to promote vigorous competition ...., the Commission can no longer defend this aspect of its opinion. ${ }^{40}$

The separate statement of Commissioner George Douglas characterized the 1978 order as "an egregiously bad order founded on a tortured economic treatment of advertising as an entry barrier." 41

The FTC's reversal of its position in the ReaLemon case followed closely on the heels of the dismissal of the FTC's complaint in the Cereals case in 1982. ${ }^{42}$ In the Cereals case, the FTC had filed a complaint in 1972 alleging that the four

n.5.

34. 43 Antitrust \& Trade Reg. Rep. (BNA) 603 (Sept. 30, 1982).

35. [1979-1983 Transfer Binder] Trade Reg. Rep. (CCH) I 21,995 (Mar. 14, 1983).

36. Borden, Inc. v. FTC, 461 U.S. 940 (1983).

37. Borden, Inc., 102 F.T.C. 1147, 1150 (1983) (contending that the Commission's "most significant policy decision in this area has been to undercut [the 1978] order after it was affirmed by a court of appeals").

38. [1979-1983 Transfer Binder] Trade Reg. Rep. (CCH) 21,995, at 22,494 (Mar. 14, 1983).

39. Id. at 22,494-95.

40. Id. at 22,495 .

41. Id. at 22,506 .

42. Kellogg Co., 99 F.T.C. 8 (1982). 
major ready-to-eat cereal manufacturers had maintained an alleged "shared monopoly" by "proliferating brands," "artificially differentiating similar products," and "promoting trademarks through intensive advertising." 43 But the ALJ dismissed the case on the ground that the evidence failed to substantiate a shared monopoly theory. ${ }^{44}$

The FTC also dismissed the antitrust monopolization claims in the Maxwell House case, in which General Foods Corporation was originally charged with engaging in "excessive promotional activities" and "using a fighting brand' to impede entry" 45 in connection with the marketing of Maxwell House Coffee. The FTC concluded that "[a]ccepting that real or perceived differences among products can build a loyal following of consumers does not amount to an acknowledgement of entry barriers." ${ }^{.46}$ More pointedly, the FTC criticized any concern that promotion of trademarks is anticompetitive: "The qualitative differences among the products and the consumers' loyalty to certain brands in the market for ground roast coffee do not indicate the kind of market power the antitrust laws were intended to address. ${ }^{\prime 47}$

The FTC's abandonment in the early 1980s of its prior position with respect to the alleged anticompetitive effect of trademarks and brand differentiation reflected more than merely a change in the political winds. The FTC's reversal reflected a shift in dominant economic thinking toward the view espoused by the "Chicago School" economists. The FTC began to reconsider the liberal economic underpinnings of the ReaLemon case even before the Sixth Circuit's affirmance. ${ }^{48}$ The FTC's shift in attitude reflected a change in the predominant thinking of economists about the value of trademarks. ${ }^{49}$

The FTC attacks on trademarks in the 1970s grew out of a Chamberlinian model of "monopolistic competition" from the 1930s, refined by the "liberal school" economists in the $1950 \mathrm{~s}$ and $1960 \mathrm{~s}^{50}$ These attacks charged that "persuasive" advertising and product differentiation formed barriers to entry. As the anti-advertising economic theories gained currency, so did the potential for antitrust attacks on the allegedly "anticompetitive" effect of trademark

43. Id. at 8-16 (reproducing complaint filed on Apr. 26, 1972); see Layne E. Kruse, Deconcentration and Section 5 of the Federal Trade Commission Act, 46 GEO. WASH. L. REV. 200 (1978).

44. Kellogg Co., 99 F.T.C. at 16-269 (reproducing initial decision of Sept. 1, 1981).

45. General Foods Corp., 103 F.T.C. 204, 332 (1984).

46. Id. at 354 .

47. Id. at 365 .

48. See Richard CRASWell, FTC Office of Pol'y Planning, FTC Policy PlanNing Issues PAPER: TRADEMARKS, CONSUMER INFORMATION AND BARRIERS TO COMPETITION 15 (1979) (commenting that if trademarks create any barriers to entry, such barriers "exist only because consumers prefer the brands with the favorable reputation and are willing to pay a higher price for them").

49. See Yale Brozen, New FTC Policy From Obsolete Economic Doctrine, 41 ANTITRUST L.J. 477 (1972).

50. Chamberlin, supra note 11 (7th ed. 1956); JOE S. BAIN, BARRIERS TO NeW COMPETITION: THEIR CHARACTER AND CONSEQUENCES IN MANUFACTURING INDUSTRIES 114-44 (1956); FREDERIC

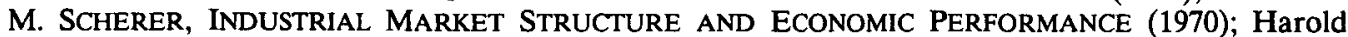
Demsetz, Barriers to Entry, 72 AM. ECON. REV. 47, 50 (1982). 
promotion. $^{51}$ Led by Chicago School economists, an equally powerful body of economic theory was developing to rebut the claim that advertising (and therefore trademarks) distorts tastes, manipulates demand, and creates anticompetitive barriers to entry. ${ }^{52}$ The filing of the ReaLemon and Cereals cases brought the economic debate to a head. The Chicago School economists contended that trademarks (and advertising) were actually pro-competitive because they lower consumer search costs, facilitate entry by new competitors, and generate quality-control incentives. ${ }^{53}$ Professor Bork argued forcefully that advertising trademarked brands does not create anticompetitive barriers to entry:

Current antitrust objections to advertising and promotion are incomprehensible, for if there is one charge that cannot with justice be laid against these activities, it is the allegation that they impair competition. They are, on the contrary, essential to vigorous market rivalry. ... Theoretical considerations indicate, therefore, that advertising and promotion cannot create artificial barriers to entry. The argument is so clear that it should come as no surprise whatever to learn that empirical work indicates the same conclusion. ${ }^{54}$

Professor Brozen forcefully argued the position that trademarks are procompetitive:

These notions-that the cost of products to consumers is high because of advertising and that advertising is a barrier to entry behind whose shelter firms behave monopolistically - are both old and obsolete. They are being adopted by the FTC staff as a basis for a complaint just at the time they are in the process of being discarded in economic analysis as erroneous-as inconsistent with economic theory and as unfounded. ${ }^{55}$

Professor Scherer, a supporter of the FTC's attacks on trademarks, shot back:

First, no amount of semantic waffling, by Posner or anyone else, can paper over the fact that the possession of a well-received brand image is a form of monopoly power.

51. Ralph S. Brown, Jr., Advertising and the Public Interests: Legal Protection of Trade Symbols, 57 YALE L.J. 1165, 1183 (1948) ("[A]dvertising is a potent device to distinguish a product from its competitors, and to create a partial immunity from the chills and fevers of competition. The result of successful differentiation is higher prices than would otherwise prevail."); Paul D. Scanlon, Oligopoly and "Deceptive" Advertising: The Cereal Industry Affair, 3 ANTITRUST L. \& ECON. REV. 99 (1970); Sara V. Dobb, Compulsory Trademark Licensure as a Remedy for Monopolization, 27 CATH. U. L. REv. 589 (1977); William C. Holmes, Trademark Licensing as Structural Antitrust Relief: An Analytical Framework, 71 TRADEMARK REP. 127, 146-47 (1981) (arguing that without compulsory trademark licensing, the effect would be "the competitive barriers raised by particularly strong trademarks thwarting competition and thereby frustrating other antitrust remedies").

52. Robert Bork, The ANTITRust Paradox: A POliCy at WaR With Itself ch. 16 (1978); Yale Brozen, Entry Barriers: Advertising and Product Differentiation, in INDUSTRIAL COMPETITION: THE NEW LEARNING 115 (Harvey J. Goldschmid et al. eds., 1974) ("Much of the behavior we observe fits the view that advertising is a means of entry and impeaches the view that it is a barrier."); Demsetz, supra note 50, at 56; Thomas Nagle, Do Advertising Profitability Studies Really Show That Advertising Creates a Barrier to Entry?, 24 J. L. \& ECON. 333 (1981).

53. Brozen, supra note 49 , at 479 ("[A]dvertising is a productive and pro-competitive activity, substituting cheaply provided information for expensive search costs, rather than being a wasteful activity producing monopolistic results.").

54. BORK, supra note 52, at 314-16.

55. Brozen, supra note 49 , at $477-78$. 
... Second, it seems to me that, at least in the consumer goods industries, image advantages confer a quantitatively important form of monopoly power-perhaps the most important. . . It is only a slight exaggeration to say that powerful trademarks could be opened up to competitive licensing at the stroke of a judicial pen. ${ }^{56}$

With the ascendancy of Chicago School economists and new lawyers at the FTC, the economic arguments in favor of trademarks and advertising generally carried the day. ${ }^{57}$ "The early 1980s, however, represented a dramatic epistemological break in the legal treatment of advertising. Now, not only are once respectable arguments thoroughly repudiated, but advertising has secured a preferred and even privileged status in contemporary antitrust doctrine." 58 In the 1980s and 1990s, the conventional wisdom has accepted the Chicago School economic and antitrust analysis favorable to advertising and trademarks. ${ }^{59}$ Without a viable economic theory, ${ }^{60}$ the era of antitrust attacks on trademarks as inherently anticompetitive has ended.

2. Trademarks and Recent Antitrust Developments Generally. The retreat of antitrust enforcement agencies from the approach of ReaLemon is not surprising in light of the general diminishment of antitrust enforcement in a variety of areas since the 1970s. More significantly, a conservatism has taken over antitrust law both at enforcement agencies and among courts and legal scholars that reflects the ascendancy of the Chicago School law and economics movement.

The Chicago School is an economic model of antitrust policy based on the neoclassical market efficiency model. ${ }^{61}$ The Chicago School seeks to apply price theory to antitrust law. ${ }^{62}$ Using the tools of price theory, the Chicago

56. Frederic M. Scherer, The Posnerian Harvest: Separating Wheat From Chaff, 86 YALE L.J. 974, 998-99 (1977); see Richard Schmalensee, On the Use of Economic Models in Antitrust: The ReaLemon Case, 127 U. PA. L. REV. 994 (1979).

57. George A. Hay, Market Power in Antitrust, 60 ANTITRUST L. J. 807, 814-17 (1992) ("[T]he mere fact that an industry is characterized by product differentiation ... need not mean that any firm has market power in the antitrust sense .... [Successful differentiation] does not signify the kind of market power the antitrust laws ought to be concerned about."); Clement G. Krouse, Brand Name as a Barrier to Entry: The ReaLemon Case, 51 S. ECON. J. 495 (1984).

58. Elizabeth Mensch \& Alan Freeman, Efficiency and Image: Advertising as an Antitrust Issue, 1990 DukE L.J. 321, 322 (1990) (describing the history of the economic and legal debate about the competitive effects of advertising).

59. 1 MCCARTHY, supra note 6, § 2.01[2]; Donald I. Baker, Compulsory Access to Network Joint Ventures Under the Sherman Act: Rules or Roulette?, 1993 UTAH L. REV. 1099-1102 (1993); Lillian R. BeVier, Competitors' Suits for False Advertising Under Section 43(a) of the Lanham Act: A Puzzle in the Law of Deception, 78 VA. L. REV. 1, 4-8 (1992) (describing the "widely but not universally shared assumption that advertising plays a benign role in facilitating market transactions"); Dan Shanahan, The Trademark Right: Consumer Protection or Monopoly?, 72 TRADEMARK REP. 233 (1982).

60. A few economists continue to assert a view of trademarks contrary to the Chicago School. See Thomas J. Campbell, Predation and Competition in Antitrust: The Case of Non-Fungible Goods, 87 COLUM. L. REV. 1625 (1987).

61. See Herbert Hovenkamp, Antitrust Policy After Chicago, 84 MICH. L. REV. 213, 215 (1985).

62. Richard Posner, The Chicago School of Antitrust Analysis, 127 U. PA. L. REV. 925,928 (1979) (noting that the price theory model includes the assumptions that "businessmen are rational profitmaximizers, . . . that demand curves slope downward, that an increase in the price of a product will reduce the demand for its complement, that resources gravitate to the areas where they will earn the 
School posits that economic efficiency is the exclusive goal of antitrust law. Professor Bork has best summarized the orthodox Chicago School position: "The whole task of antitrust can be summed up as the effort to improve allocative efficiency without impairing productive efficiency so greatly as to produce either no gain or a net loss in consumer welfare." ${ }^{\prime 63}$ In this model, "[c]onsumer welfare ... permits consumers to define by their expression of wants in the marketplace what things they regard as wealth."

Although many of the positions of the Chicago School are controversial, the influence of the Chicago School on antitrust law and policy is unquestioned. ${ }^{65}$ The impact of the Chicago School law and economics approach in changing antitrust law has been well documented. ${ }^{66}$ The ascendancy of the Chicago School has been at the expense of the Harvard School, industrial organization, economists, and the Warren Court antitrust doctrines. ${ }^{67}$ These industrial organization economists focused heavily on the evils of oligopolistic markets, product differentiation, industrial concentration, barriers to entry, and large firm dominance. ${ }^{68}$ In contrast, the Chicago School approach was that "firms cannot in general obtain or enhance monopoly power by unilateral action" and that "the focus of the antitrust laws should not be on unilateral action" but rather on horizontal price-fixing cartels and horizontal mergers that create monopolies. ${ }^{69}$ Chicago School scholars were especially critical of the Warren Era adoption of per se rules of antitrust illegality for unilateral conduct such as predatory pricing and for vertical restraints such as resale price maintenance, exclusive territorial restrictions, and tie-ins (requiring a buyer to buy a second product as a condition for buying the first product). ${ }^{70}$

The economic theories of the Chicago School ultimately came to influence strongly not only the Justice Department and the FTC but also the federal courts. The seminal case was the Supreme Court's 1977 decision in Sylvania, where the Court abandoned the per se rule of illegality for vertical territorial restraints under the Sherman Act and adopted a flexible Rule of Reason to

highest return").

63. BORK, supra note 52, at 91 ("Allocative efficiency, as used here, refers to the placement of resources in the economy, the question of whether resources are employed in tasks where consumers value their output most. Productive efficiency refers to the effective use of resources by particular firms. The idea of effective use ... encompasses much more than mere technical or plant-level efficiency.").

64. Id. at 90.

65. Hovenkamp, supra note 61, at 214-16.

66. Pete M. Gerhart, The Supreme Court and Antitrust Analysis: The (Near) Triumph of the Chicago School, 1982 SUP. CT. REV. 319; William H. Page, The Chicago School and the Evolution of Antitrust: Characterization, Antitrust Injury, and Evidentiary Sufficiency, 75 VA. L. REV. 1221 (1989).

67. See Hovenkamp, supra note 61 , at 217.

68. See Joe Bain, Barriers to New COMPETITION: THeir Character and ConsequenCES IN MANUFACTURING INDUSTRIES (1956); Hovenkamp, supra note 61, at 218-19.

69. Posner, supra note 62, at 928-48 (contending that the views of the Harvard School and the Chicago School had begun to converge as many of the assumptions of the Chicago School met general acceptance).

70. Id. at 926-27; BORK supra note 52, at 280-407. 
assess such a vertical restraint. ${ }^{71}$ The Sylvania decision adopted the Chicago School approach that restraints on intrabrand competition were of lesser concern because, by enhancing brand promotion, intrabrand restraints promote interbrand competition among producers. ${ }^{72}$ The Supreme Court accepted the argument that a vertical restraint imposed by a single manufacturer on dealers is unlikely to have anticompetitive consequences because interbrand competition confronting the manufacturer effectively checks the exploitation of intrabrand market power. Consumers can readily substitute a different brand of the same product. ${ }^{73}$ The Sylvania decision launched the Supreme Court and federal antitrust law generally into an era in which the courts began to employ routinely the economic analysis of efficiency, reconsider prior antitrust precedent, and adopt the Rule of Reason (explicitly or implicitly) to assess many challenged practices. $^{74}$ Despite the great influence of the Chicago School, however, the Supreme Court has not uniformly adopted its views on all antitrust issues, as evidenced by the Court's 1992 decision in Kodak. ${ }^{75}$

The Chicago School approach to antitrust law has had an inevitable effect on antitrust cases involving trademarks. As discussed infra, the implications of Chicago School economics has also had an effect on substantive trademark law. The most significant implication of the Chicago School analysis for trademarks arises from its criticism of the view that advertising and promotion create artificial barriers to entry. ${ }^{76}$ The Chicago School has adopted the view that "all of the 'artificial barriers' complained of in antitrust are, in fact, activities that create efficiency." 77 The Chicago School argues that any market power associated with a trademark is derived merely from the buyer's preference for

71. Continental T.V., Inc. v. GTE Sylvania, Inc., 433 U.S. 36 (1977).

72. Id. at $52 \mathrm{n} .19$ (interbrand competition is the "primary concern of antitrust law"); see Richard Posner, The Rule of Reason and the Economic Approach: Reflections on the Sylvania Decision, 45 U. CHI. L. REV. 1 (1977).

73. Sylvania, 433 U.S. at 52 n.19.

74. Brooke Group, Ltd. v. Brown \& Williamson Tobacco Corp., 509 U.S. 209 (1993); Business Elecs. Corp. v. Sharp Elecs. Corp., 485 U.S. 717 (1988) (limiting extent of per se prohibition of resale price maintenance); Matsushita Elec. Indus. Co. v. Zenith Radio Corp., 475 U.S. 574 (1986) (approving summary judgment on antitrust claims based on economically irrational conduct); Northwest Wholesale Stationers, Inc. v. Pacific Stationery and Printing Co., 472 U.S. 284 (1985) (limiting scope of per se rule for concerted refusals to deal); Jefferson Parish Hospital District No. 2 v. Hyde, 466 U.S. 2 (1984) (adopting rule of reason for exclusive contracts, and inquiring into market power for tie-ins); see Frank H. Easterbrook, The Limits of Antitrust, 63 TEX. L. REV. 1, 9-14 (1984).

75. Eastman Kodak Co. v. Image Technical Servs., Inc., 504 U.S. 451 (1992) (ruling that nonstructural market power justified reversal of summary judgment in tying case); see Robert $H$. Lande, Chicago Takes it on the Chin: Imperfect Information Could Play a Crucial Role in the Post-Kodak World, 62 ANTITRUST L.J. 193 (1993); M. Sean Royall, Symposium: Post-Chicago Economics, 63 ANTITRUST L.J. 445 (1995).

76. BORK, supra note 52, at 314-20.

77. Id. at 196 ("The Chicago School's view of advertising is especially noteworthy because of the importance that advertising had assumed in the Harvard thinking on antitrust."); Posner, supra note 62, at 930 . 
the trademarked product and, thus, is not an anticompetitive barrier to entry with which the antitrust laws should be concerned. ${ }^{78}$

Section 33(b)(7) of the Lanham Act provides a defense to trademark infringement whenever it is established " $[\mathrm{t}]$ hat the mark has been or is being used to violate the antitrust laws of the United States." antitrust trademark "misuse" has been rarely invoked because the courts interpret the Lanham Act as requiring "proof that the mark itself has been the basic and fundamental vehicle required and used to accomplish the violation," as opposed to "proof of a collateral violation." 80

Until the ReaLemon case, courts generally did not find that the mere aggressive use and promotion of trademarks could itself constitute monopolization or attempted monopolization under Section 2 of the Sherman Act. ${ }^{81}$ But the Supreme Court has struck down territorial trademark licensing agreements that were held to constitute horizontal agreements among competitors to divide markets. $^{82}$

The most frequently litigated antitrust cases involving trademarks have been tying cases. A tying arrangement is "an agreement by a party to sell one product but only on the condition that the buyer also purchases a different (or tied) product." ${ }^{\prime 3}$ Since at least the International Salt decision in 1947, tie-ins have been held to be per se violations of Section 1 of the Sherman Act. ${ }^{84}$ An essential element to establish an illegal tying arrangement has traditionally been proof of sufficient economic power in the tying product to impose restrictions sufficient to restrain competition in the tied product market. ${ }^{85}$ In other words, the seller must have sufficient economic power over the tying product to be able to compel buyers to purchase the tied product. The Supreme Court in some early cases adopted the presumption of market power in the tying product where it was either patented or copyrighted. ${ }^{86}$

78. BoRK, supra note 52, at 310; Thomas C. Arthur, The Costly Quest for Perfect Competition: Kodak and Nonstructural Market Power, 69 N.Y.U. L. REV. 1, $41-42$ (1994).

79. 15 U.S.C. $\$ 1115$ (b)(7) (1994).

80. Carl Zeiss Stiftung v. V.E.B. Carl Zeiss, Jena, 298 F. Supp. 1309, 1315 (S.D.N.Y. 1969), modified on other grounds, 433 F.2d 686 (2d Cir. 1970), cert. denied, 403 U.S. 905 (1971). Compare Phi Delta Theta Fraternity v. J. A. Buchroeder \& Co., 251 F. Supp. 968 (W.D. Mo. 1966) (allowing antitrust misuse defense where trademark used directly in antitrust violation) with Coca-Cola Co. v. Howard Johnson Co., 386 F. Supp. 330 (N.D. Ga. 1.974) (striking misuse defense where complaint asserted collateral antitrust activities with respect to trademarked goods); see David Hill, Antitrust Violations as a Defense to Trademark Infringement, 71 TRADEMARK REP. 148 (1981).

81. Drop Dead Co. v. S. C. Johnson \& Son, Inc., 326 F.2d 87, 95 (9th Cir. 1963), cert. denied, 377 U.S. 907 (1964) (promoting trademarks constituted mere "aggressive competition"); see 1 MCCARTHY, supra note $6, \S 31.26[3][\mathrm{a}]$, at 31-143.

82. United States v. Topco Assocs., 405 U.S. 596 (1972); United States v. Sealy, Inc., 388 U.S. 350 (1967); Timken Roller Bearing Co. v. United States, 341 U.S. 593 (1951). But see VMG Enters., Inc. v. F. Quesada \& Franco, Inc., 788 F. Supp. 648, 653-59 (D.P.R. 1992).

83. Northern Pac. Ry. Co. v. United States, 356 U.S. 1, 5-6 (1958).

84. International Salt Co. v. United States, 332 U.S. 392 (1947).

85. Northern Pac. Ry. Co., 356 U.S. at 6.

86. United States v. Loew's, Inc., 371 U.S. 38, 45 (1962) ("Requisite economic power is presumed when the tying product is patented or copyrighted."). 
In 1971, the Ninth Circuit extended tying analysis to trademarks in Siegel $v$. Chicken Delight, Inc. ${ }^{87}$ In holding that a franchisor may not condition a license to use its trademark on the franchisees' reciprocal purchase of supplies and equipment, the Ninth Circuit found that sufficient market power could be presumed to exist when the tying product is a trademark. ${ }^{88}$ The lower courts subsequently split on whether trademarks could be the basis for a tying claim. ${ }^{89}$ Adherents of the Chicago School, who doubted that tying arrangements should even be unlawful, ${ }^{90}$ were particularly critical of any presumption that a trademark could be the basis for market power in a tying product. ${ }^{91}$

In 1984, the Supreme Court narrowly reaffirmed the per se rule against tying in the Jefferson Parish case, and it demanded real economic proof of market power in tying products. ${ }^{92}$ Since Jefferson Parish, the lower courts have consistently refused to hold that trademarks themselves confer market power for purposes of tying arrangements. ${ }^{93}$ Without even mentioning Siegel, the Ninth Circuit subsequently held in 1987 that "a prestigious trademark is not itself persuasive evidence of economic power. . . . Market power, if any, is derived from the product, not from the name or symbol as such." 94

87. 448 F.2d 43 (9th Cir. 1971), cert. denied, 405 U.S. 955 (1972).

88. The court reasoned that "[j] ust as the patent or copyright forecloses competitors from offering the distinctive product on the market, so the registered trade-mark presents a legal barrier against competition." Id. at 50 .

89. Compare Warriner Hermetics, Inc. v. Copeland Refrig. Corp., 463 F.2d 1002, 1015 (5th Cir.), cert. denied, 409 U.S. 1086 (1972) ("The Copeland trade-mark . . . is persuasive evidence of significant market leverage.") with Capital Temporaries, Inc. v. Olsten Corp., 506 F.2d 658, 663 (2d Cir. 1974), Principe v. McDonald's Corp., 631 F.2d 303 (4th Cir. 1980), cert. denied, 451 U.S. 970 (1981) (holding that the McDonald's franchise was not separable into two products), and Carpa, Inc. v. Ward Foods, Inc., 536 F.2d 39, 48 (5th Cir. 1976) (stating that the court had not gone "so far as to presume that the mere existence of a trademark in and of itself supplies economic power sufficient to constitute an antitrust violation").

90. Posner, supra note 62, at 926; BORK, supra note 52, at 363-81 ("A review of the cases and the economics of tying and reciprocity, then, leads inescapably to the conclusion that the law in this field is unjustified and is itself inflicting harm upon consumers.").

91. William Hensley, Franchise Tying: Gauging the Economic Power of a Trademark, U.C. DAVIS L. REV. 405 (1981); Warren Lavey, Patents, Copyrights and Trademarks as Sources of Market Power in Antitrust Cases, 27 ANTITRUST BULL. 433, 448-51, 454-55 (1982) ("Patents, copyrights, and trademarks are forms of intellectual property; they are often not economic monopolies. Describing them as monopolies can impair proper economic analysis in antitrust cases as well as proper economic analysis of the laws granting intellectual property."); William Montgomery, The Presumption of Economic Power for Patented and Copyrighted Products in Tying Arrangements, 85 CoLUM. L. REV. 1140 (1985).

92. Jefferson Parish Hospital District No. 2 v. Hyde, 466 U.S. 2, 16 (1984). Four justices, in consideration of the potential pro-competitive effects of tying arrangements, would have analyzed the restraints under the Rule of Reason. Id. at 32-34.

93. See, e.g., Town Sound \& Custom Tops, Inc. v. Chrysler Motor Corp., 743 F. Supp. 353, 359 (E.D. Pa.), aff'd in part, rev'd in part on other grounds, 959 F.2d 468 (3d Cir.) (en banc), cert. denied, 506 U.S. 868 (1992); Grappone v. Subaru of New England, 858 F.2d 792, 798 (1st Cir. 1988); Will v. Comprehensive Accounting Corp., 776 F.2d 665, 673 n.4 (7th Cir. 1985), cert. denied, 475 U.S. 1129 (1986).

94. Mozart Co. v. Mercedes-Benz of N. Am., Inc., 833 F.2d 1342, 1346 (9th Cir. 1987), cert. denied, 488 U.S. 870 (1988). 
The leading antitrust treatise, consistent with the Chicago School's general attitude toward trademarks and barriers to entry, has essentially adopted the view that trademarks are not anticompetitive:
A trademark is even less potent than a copyright in bringing its owner market power. It protects nothing more than one's name, allowing rivals to copy every detail of a rival's business (short of passing oneself off as another). While a defendant might dominate a market because of the reputation enjoyed by its name, nothing prevents rivals from offering equivalent products and establishing a matching reputation. Barriers to entry may exist, but the legal protection afforded the defendant's name is not what bars entry. . . . Nor would trademarks indicate power often enough to be a convenient surrogate for proof of power. In sum, the holder of a protected trademark may enjoy market power, but such power cannot be inferred from the trademark alone. $^{95}$

In 1995, the federal antitrust enforcement agencies published intellectual property guidelines intended to set forth the federal government's enforcement policies related to licensing of intellectual property. ${ }^{96}$ While they do not cover the antitrust treatment of trademarks, the Guidelines note that "the same general antitrust principles that apply to other forms of intellectual property apply to trademarks as well." 97 The Guidelines are significant because of their generally favorable and supportive attitude toward intellectual property rights. In its statement of general principles, the Guidelines announce that "the Agencies do not presume that intellectual property creates market power in the antitrust context," and "the Agencies recognize that intellectual property licensing allows firms to combine complementary factors of production and is generally pro-competitive." 98 The Guidelines take a relatively benign view of the exclusive rights accorded to owners of patents, copyrights, and trade secrets: "Intellectual property is thus neither particularly free from scrutiny under the antitrust laws, nor particularly suspect under them." In a seeming departure from the FTC's attitude in the 1970s, the Guidelines make clear that the mere possession of an intellectual property right will not give rise to a presumption of market power and cannot in itself be the basis of an antitrust violation: "If a patent or other form of intellectual property does confer market power, that market power does not by itself offend the antitrust laws."100 Although the Guidelines do not address trademark antitrust issues, it is clear that the federal enforcement agencies view all intellectual property as generally pro-competitive: "The intellectual property laws and the antitrust laws share the common purpose of promoting innovation and enhancing consumer welfare."101 Thus,

95. X Phillip Areeda et AL., ANTitrust Law II 1737e (1995).

96. Department of Justice \& Federal Trade Commission, Antitrust Guidelines for the Licensing of Intellectual Property $\$ 1.0$ (1995), reprinted in 4 TRADE REG. REP. (CCH) $\$ 13,132$, at 20,733 (Apr. 6, 1995) [hereinafter Guidelines].

97. Id. $\& 1.0 \mathrm{n} .1$ (noting that "product-differentiation issues ... typically arise with respect to trademarks").

98. Id. \& 2.0 .

99. Id. $\S 2.1$.

100. Id. $\$ 2.2$.

101. Id. $\S 1.0$. 
the Guidelines are significant because they state the government's antitrust policy in support of intellectual property. Legal commentators have also noted the marked shift in antitrust law in the 1980s and 1990s favorable to all forms of intellectual property. ${ }^{102}$

B. Expanded Protection in Traditional Trademark Infringement Cases: The Ascendancy of Chicago School Law and Economics Theory

Trademark infringement cases have shown the slow evolution of legal doctrine since the 1970s. As trademark law matures and as the courts develop precedent interpreting the Lanham Act, established legal doctrines tend to take on a certain sanctity. ${ }^{103}$ Thus, "likelihood of confusion" between two marks by consumers has become the hallmark concept litigated in trademark infringement cases. ${ }^{104}$ Likewise, in determining the initial validity of a trademark, the traditional trademark legal doctrine assessing marks as generic/descriptive/suggestive/arbitrary has not changed substantially. ${ }^{105}$ However, because such decisions concentrate so heavily on the facts of a particular case, and because this legal doctrine tends to become formalistic and conceptualistic, there is much room for judicial discretion. As legal realism has taught us, judicial discretion is exercised within the context of broader political and intellectual trends of the times. Therefore, as society and the courts have become more politically conservative, the trend in infringement cases has been toward greater protection for trademarks within the general doctrinal confines of the Lanham Act. The theoretical underpinning for expanded protection has been the economic theories of the Chicago School.

1. The Chicago School Defense of Trademarks. Just as the Chicago School theorists have come to dominate thinking in antitrust law, so has the Chicago School influenced the development of basic trademark law. Even though many courts do not explicitly assess economic issues in deciding trademark cases, ${ }^{106}$

102. See XI Phillip Areeda et al, ANTitrust Law II 1783 (1996); James B. Kobak, Jr., Running the Gauntlet: Antitrust and Intellectual Property Pitfalls on the Two Sides of the Atlantic, 64 ANTITRUST L.J. 341, 349 (1996) ("Intellectual property rights and their enforcement are no longer regarded as inherently evil. They are no longer seen as irreconcilably inconsistent with the goals of antitrust."); Norman E. Rosen, Intellectual Property and the Antitrust Pendulum: Recent Developments at the Interface Between the Antitrust and Intellectual Property Laws, 62 ANTITRUST L.J. 669 (1994).

103. The promulgation in 1993 of the Third Restatement has served to give trademark law the appearance of being largely settled. See RESTATEMENT (THIRD) OF UNFAIR COMPETITION (1995).

104. See Patricia Kaeding, Clearly Erroneous Review of Mixed Questions of Law and Fact: The Likelihood of Confusion Determination in Trademark Law, 59 U. CHI. L. REV. 1291, 1292-93 (1992); see, e.g., Centaur Communications, Ltd. v. A/S/M Communications, Inc., 830 F.2d 1217, 1225 (2d Cir. 1987) (citing Polaroid Corp. v. Polarad Elec. Corp., 287 F.2d 492, 495 (2d Cir.), cert. denied, 368 U.S. 820 (1961)); New West Corp. v. NYM Co., 595 F.2d 1194, 1201 (9th Cir. 1979).

105. Abercrombie \& Fitch Co. v. Hunting World, Inc., 537 F.2d 4, 9 (2d Cir. 1976); RESTATEMENT (THIRD) OF UNFAIR COMPETITION $\$ \$ 9-15$ (1995) [hereinafter THIRD RESTATEMENT].

106. The Restatement has recognized the general principle that trademark infringement actions are an exception to the general principle of non-liability for injury caused by one competitor as a result of free competition and that trademark law requires a balancing of the public interest: 
the Chicago School approach has had an undeniable impact on trademark cases across the board. In most instances, that impact has been supportive of existing trademark legal doctrine and trademark protection generally.

The approach of the Chicago School to trademarks was reflected judicially in two Seventh Circuit opinions in 1985 authored by two judges who are leaders of the Chicago School, Judges Frank Easterbrook and Richard Posner. In the first case, Scandia Down, ${ }^{107}$ Judge Easterbrook took the opportunity to describe succinctly the economic benefit that the Chicago School sees in trademarks:

Trademarks help consumers to select goods. By identifying the source of the goods, they convey valuable information to consumers at lower costs. Easily identified trademarks reduce the costs consumers incur in searching for what they desire, and the lower the costs of search the more competitive the market. A trademark also may induce the supplier of goods to make higher quality products and to adhere to a consistent level of quality. ${ }^{108}$

In Scandia, the Seventh Circuit explained aspects of traditional trademark doctrine in economic terms. The first issue addressed by the Court was whether the words "Down Shop[pe]" used with Scandia's logo of a goose was "merely descriptive" (in which case protection would be denied) or "arbitrary" or "suggestive" (in which case Scandia's mark would be protected). ${ }^{109}$ The Seventh Circuit sided with Scandia and affirmed the lower court's assessment of the evidence that the mark was protectable. The second issue in the case was whether the trademark of the competitor, Euroquilt, was "confusingly similar" to Scandia's trademark. ${ }^{110}$ Again, the Seventh Circuit affirmed the trial court's determination of likelihood of confusion. Significantly, Judge Easterbrook analyzed these issues in economic terms: "Confusingly similar marks make consumers' task in searching for products harder."111 Judge Easterbrook drew the comparison to antitrust cases "where retailers may try to take a free ride on the services provided by their rivals." 112 By enjoining trademark infringement, the "free rider" effect could be prevented. However, Judge Easterbrook emphasized that a trademark holder could not obtain rights to merely

The rules governing the protection of trademarks must also be responsive to the public interest in fostering vigorous competition. In defining protectable subject matter and in delineating the scope of exclusive rights, the law cannot neglect the legitimate interests of other competitors. In some cases the recognition of exclusive rights in favor of a particular seller may undermine the ability of other sellers to communicate useful information to consumers or deprive competitors of access to product features necessary for effective competition.

THIRD RESTATEMENT, supra note $105, \S 1 \mathrm{cmt}$. e.

107. Scandia Down Corp. v. Euroquilt, Inc., 772 F.2d 1423 (7th Cir. 1985), cert. denied, 475 U.S. 1147 (1986).

108. Id. at 1429 .

109. Id at 1430 .

110. Id. at 1431 .

111. Id. at 1430 .

112. Id. 
descriptive words because that would constitute "a free ride on the language." $" 113$

In W. T. Rogers, ${ }^{114}$ the Seventh Circuit reversed a jury verdict for the defendant, a manufacturer of plastic stacking letter trays who sued for trademark infringement under $\S 43(a)$ of the Lanham Act. ${ }^{115}$ The court considered the limits of the "functionality doctrine" in trademark law. This doctrine falls right at the intersection of trademark protection and competition.

[T] he concept of functionality is intended to screen out from the protection of trademark law certain design features even if they have become so far identified with the manufacturer of a particular brand that consumers may be confused about the origin of the good if another producer is allowed to adopt the feature. ${ }^{116}$

Traditionally, the rule has stipulated that functional features may be protected as trademarks "unless competition is unduly hindered" thereby. ${ }^{117}$ Judge Posner analyzed trademark law and the functionality defense in economic terms using a Chicago School approach. ${ }^{118}$

The reason for this screen or filter [of the functionality doctrine] becomes apparent once the purpose of trademark protection is understood ... . The purpose is to reduce the cost of information to consumers by making it easy for them to identify the products or producers with which they have had either good experiences, so that they want to keep buying the product (or buying from the producer), or bad experiences, so that they want to avoid the product or the producer in the future.

In W. T. Rogers, Judge Posner announced that "competition is not impaired by giving each manufacturer a perpetual 'monopoly' of his identifying mark" if he has chosen a "distinctive" trademark where the available names are "for all practical purposes infinite." 119 Judge Posner noted that "generic" names are not subject to trademark protection because the manufacturer there "is trying to monopolize a scarce input, for there usually are only one or two words in common usage to describe a given product (such as 'car' and 'automobile')."120 Likewise, inclusion in a trademark of a design feature that is intrinsic to the entire product will result in a denial of protection under the "functionality doctrine." In such a case, "that firm would have, not an identifying mark, but a product monopoly, and a product monopoly not for a term of years as under the patent laws but forever." ${ }^{21}$ In that case, competition would be hindered because "a functional feature is one which competitors would have to spend money not to copy but to design around." ${ }^{122}$ Judge Posner concluded by placing this issue of trademark law in the starkest competitive terms:

113. Id.

114. W. T. Rogers Co., Inc. v. Keene, 778 F.2d 334 (7th Cir. 1985).

115. 15 U.S.C. $\$ 1125$ (a) (1994).

116. W.T. Rogers, 778 F.2d at 338.

117. Id.; see Jessica Litman, Note, The Problem of Functional Features: Trade Dress Infringement Under Section 43(a) of the Lanham Act, 82 COLUM. L. REV. 77, $81-93$ (1982).

118. W.T. Rogers, 778 F.2d at 338.

119. Id. at 339 .

120. Id.

121. Id.

122. Id. 
[T] he jury has to determine whether the feature for which trademark protection is sought is something that other producers of the product in question would have to have as part of the product in order to be able to compete effectively in the market-in other words, in order to give consumers the benefits of a competitive market-or whether it is the kind of merely incidental feature which gives the brand some individual distinction but which producers of competing brands can readily do without. ${ }^{123}$

Significantly, these Chicago School judicial opinions purport to expressly reject a formalistic or conceptualistic approach to trademark protection. Although finding in favor of protection and essentially justifying pre-existing legal doctrines, the Seventh Circuit took pains to avoid reaching a decision deductively from the concepts and language familiar to trademark lawyers. In its place, the Seventh Circuit applied a very pragmatic economic analysis. ${ }^{124}$

We have said before that "arbitrary," "suggestive," and the other words in the vocabulary of trademark law may confuse more readily than they illuminate . . , a caution litigants should take seriously before arguing cases so that everything turns on which word we pick. It is better to analyze trademark cases in terms of the functions of trademarks.

So the ultimate legacy of the legal realists' attack on formalism is that the "law and economics" analysis of Chicago School judges provides a new and sounder theoretical underpinning for traditional trademark legal doctrine. What would the legal realists of the 1930s think if they could have foreseen that their attack on formalist conceptualism in trademark law would eventually result in an expanded protection for trademarks in the form of fact-based economic analysis of the functions of trademarks? The Chicago School judges have taken to heart the legal realists' critique that cases should not be decided by deductively reasoning from simple rules or words. ${ }^{125}$ So instead of purporting to reason deductively from such open-textured or vague trademark rules defining what is "generic" or "descriptive" or "suggestive," the Chicago School judges are intent on "looking behind" the facade of legal trademark doctrine to assess the purposes and policies underlying trademark law in economic terms. The irony is that a somewhat radical movement such as legal realism has had its mode of legal reasoning borrowed and made the basis for a conservative economic approach to decisionmaking in trademark law. Similarly, in antitrust law, the Chicago School approach may also be seen as the descendant of legal

123. Id.; see Kohler Co. v. Moen, Inc., 12 F.3d 632, 643 (7th Cir. 1993) (emphasizing that trademark protection is not anticompetitive).

124. Scandia, 772 F.2d at 1431 n.3.

125. "[O]ne ... sees interesting cases slaughtered every day by lawyers who parrot the language of older cases rather than figuring out the functional considerations." Frank $\mathrm{H}$. Easterbrook, Intellectual Property is Still Property, 13 HARV. J. L. \& PUB. POL'Y 108, 118 (1990); see EdWARD H. LeVI, AN INTRODUCTION TO LEGAL REASONING 1 (1949) ("It is important that the mechanism of legal reasoning should not be concealed by [the] pretense ... that the law is a system of known rules applied by a judge; the pretense has long been under attack."); Scott Brewer, Exemplary Reasoning: Semantics, Pragmatics, and the Rational Force of Legal Argument by Analogy, 109 HARV. L. REV. 923, 930-33 (1996); Richard A. Posner, Legal Formalism, Legal Realism, and the Interpretation of Statutes and the Constitution, 37 CASE W. RES. L. REV. 179 (1986). 
realism, even though the Chicago scholars challenged formalism "by applying a brand of economic theory that expressed more rigorously the same laissezfaire vision that the realists had attacked decades before."126

These Chicago School judicial decisions have been accompanied by a series of journal articles in support of the economic theory of trademark protection. The most influential articles, The Economics of Trademark Law and Trademark Law: An Economic Perspective, were by two of the leading lights of the Chicago School, William Landes and Richard Posner. ${ }^{127}$ The appeal of the Chicago School economic theory is that it has the capacity to provide an all-encompassing and unifying approach to virtually every legal issue in trademark law. The function of trademark law is reduced to a single goal of economic efficiency to maximize wealth. ${ }^{128}$ Much of existing trademark legal doctrine can then be "explained" in terms of the economic function of trademarks. This economic approach places less emphasis on other ideas that have historically been viewed as animating goals of trademark law, such as commercial morality, preventing consumer deception, and protecting a trademark owner's business goodwill from misappropriation. The Chicago School approach purports to subsume these varied ideas in a single economic theory.

The general approach of the Chicago School has been widely accepted, partly as a result of the absence of any countervailing arguments by the socalled Harvard School of economic theory. Without a countervailing economic theory, such as that proposed by Edward Chamberlin in the 1930s and advanced later by Harvard School economists through the 1960s, the Chicago School analysis remains largely unchallenged. ${ }^{129}$ The leading treatise summarizing

126. See William H. Page, Legal Realism and the Shaping of Modern Antitrust, 44 EMORY L.J. 1, 4 (1995).

127. William M. Landes \& Richard A. Posner, The Economics of Trademark Law, 78 TRADEMARK REP. 267, 271-72 (1988); William M. Landes \& Richard A. Posner, Trademark Law: An Economic Perspective, 30 J. L. \& ECON. 265, 290 (1987); see John F. Coverdale, Note, Trademarks and Generic Words: An Effect-On-Competition Test, 51 U. CHI. L. REv. 868 (1984); Ralph H. Folsom \& Larry L. Teply, Trademarked Generic Words, 89 YALE L.J. 1323 (1980); Roger E. Meiners \& Robert J. Staaf, Patents, Copyrights and Trademarks: Property or Monopoly?, 13 HARV. J. L. \& PUB. POL'Y 911 (1990); Peter E. Mims, Note, Promotional Goods and Functionality Doctrine: An Economic Model of Trademarks, 63 TEX. L. REV. 639 (1984).

128. "The basic function of law in an economic or wealth-maximization perspective is to alter incentives." RICHARD A. POSNER, THE ECONOMICS OF JUSTICE 75 (1981).

129. Not all economists share the Chicago School view that the law's function is the maximization of wealth. POSNER, supra note 128 , at $48-115$. The Chicago School approach to law and economics has been criticized on the ground that it "ignores the broader economic understanding of the legal system as an order derived from the adjudication of individual claims rather than from a public policy blueprint." Tom G. Palmer, Intellectual Property: A Non-Posnerian Law and Economics Approach, 12 Hamline L. REV. 261, 303 (1989). Palmer has argued that the Chicago School is wrong to view intellectual property law as functioning to achieve a specific outcome of efficiency and wealth maximization, instead of allowing the legal order to develop rules spontaneously case by case as courts attempt to do justice and recognize rights in each case. Id. at 263,303-04. And the protection of patents and copyrights has generated greater debate among economists than the protection of trademark rights. Compare William M. Landes \& Richard A. Posner, An Economic Analysis of Copyright Law, 18 J. LEGAL STUD. 325 (1989) with Palmer, supra, at 263 ("[P]atents and copyrights are forms, not of legitimate property rights, but of illegitimate state-granted monopoly."). 
trademark law has essentially embraced the Chicago School view of the value of trademarks for the competitive market in identifying the source of the goods, encouraging maintenance of quality products, and reducing consumers' search costs. ${ }^{130}$ In short, existing trademark legal doctrine is seen as providing a solution to the tension between protection of trademarks and free competition, and resolves that tension either by denying the existence of any conflict or by determining that existing exceptions to rules of protection are sufficient to accommodate any tension.

Supporters of the economic approach to trademark law differ as to whether that approach is consistent with a "property rights" view of trademarks. Professor Carter expressed the view that the economic goals of trademark law are fundamentally an utilitarian argument for efficiency. ${ }^{131}$ Judge Easterbrook argues for the libertarian position that the economic function of trademarks is simply an aspect of property rights. ${ }^{132}$ Easterbrook's view suggests that an economic approach to trademark law is capable of eliminating any conflict between competition and property rights, policy and morality, utilitarianism and natural rights.

2. The Supreme Court Embraces the Economic Justification for Trademarks. In traditional trademark infringement cases under the Lanham Act, ${ }^{133}$ the trend, to the extent any can be discerned in the 1980s and 1990s, is toward greater protection of trademarks and expanded standards for what symbols and devices can qualify as trademarks. The judicial attitude toward trademarks is best exemplified by the recent decisions of the Supreme Court interpreting the Lanham Act. In its relatively few trademark cases in the past twenty years, the high Court has embraced a relatively hospitable view of trademarks and trademark protection. ${ }^{134}$

In Park ' $N$ Fly, Inc. v. Dollar Park and Fly, Inc., the Supreme Court expanded trademark protection by holding that even a trademark that was "merely descriptive" would support an infringement action where the trademark had become "incontestable" under the Lanham Act. ${ }^{135}$ The plaintiff had a registered service mark, "Park "N Fly," that it used in the operation of longterm parking lots near airports. The service mark had achieved incontestable

130. 1 MCCARTHY, supra note $6, \$ 2.01[2]$.

131. Stephen L. Carter, Owning What Doesn't Exist, 13 HARv. J. L. \& PUB. POL'Y 99, 101 (1990).

132. Easterbrook, supra note 125 , at 112.

133. 15 U.S.C. $\& 1114(1)(1994)$.

134. In Inwood Laboratories, Inc. v. Ives Laboratories, Inc., 456 U.S. 844 (1982), the court noted that it was undisputed that pharmacists who mislabeled generic drugs with the plaintiff's registered trademark violated $\S 32$ of the Lanham Act, although the Court declined to extend liability vicariously to manufacturers of the generic drugs. In discussing the pharmacists' mislabeling, Justice O'Connor noted that "blatant trademark infringement inhibits competition" because "the infringer deprives the owner of the good will which he spent energy, time, and money to obtain" and because infringement "deprives consumers of their ability to distinguish the goods of competing manufacturers." Id. at 854 n. 14.

135. 469 U.S. 189 (1985). 
status under the Lanham Act ${ }^{136}$ because the mark had been registered and had been in continuous use for five consecutive years without any decisions adverse to the registration. The owner of the "Park " $\mathrm{N}$ Fly" trademark brought an infringement action to enjoin use by a competitor of the words "Park and Fly." The Court broadly construed the incontestability provision of the Lanham Act, preventing the defendant from establishing that "Park ' $\mathrm{N}$ Fly" was merely descriptive of the product and had not acquired "secondary meaning." 137 In the absence of the incontestability provision, such a merely descriptive mark (one that merely describes the qualities and characteristics of the good or service) would not be entitled to trademark protection.

What is impressive about the Court's opinion in Park ' $N$ Fly is that the Court was relatively unconcerned with the potential anticompetitive effects of allowing a merely descriptive trademark to receive protection. The Court concluded that the legislative history of the Lanham Act supported the view that "[n]ational protection of trademarks is desirable . . . because trademarks foster competition and the maintenance of quality by securing to the producer the benefits of good reputation." 138 The Court brushed aside any concern about the anticompetitive effect of taking "from the public domain language that is merely descriptive."139 The Court dismissed any concerns about "commercial monopolization" of descriptive language by indicating that a mark could be challenged at any time "if it becomes generic" and that any threat to economic competition could always be challenged under the trademark misuse provision of Section 33(b)(7) of the Lanham Act ${ }^{140}$ that "provides a defense on the grounds that the mark is being used to violate federal antitrust laws."141 Instead, by allowing an infringement action for a merely descriptive mark, the Court implicitly indicated its view that trademark protection in this context would have minimal anticompetitive consequences and perhaps even serve a pro-competitive purpose. ${ }^{142}$

In Two Pesos, Inc. v. Taco Cabana ${ }^{143}$ the Supreme Court in 1992 brought trade dress law into the mainstream of trademark law. Section 43(a) of the Lanham $\mathrm{Act}^{144}$ has been interpreted to create a federal cause of action for

136. 15 U.S.C. $\S \S 1065,1115(b)$ (1994).

137. Park 'N Fly, 469 U.S. at 205.

138. Id. at 198.

139. Id. at 201.

140. 15 U.S.C. $\S 1115(b)(7)$ (1994).

141. Park 'N Fly, 469 U.S. at 201.

142. Although the Court justified its results in terms of the economic benefits of trademarks, the Court's Park 'N Fly opinion has been criticized as going beyond the economic rationale for trademark protection. See Suman Naresh, Incontestability and Rights in Descriptive Trademarks, 53 U. CHI. L. REV. 953, 986-87 (1986).

143. 505 U.S. 763 (1992).

144. Section 1125 states, in relevant part:

Any person who shall ... use in connection with any goods or services, or any container or containers for goods ... any false description or representation, including words or other symbols tending falsely to describe or represent the same, ... shall be liable to a civil action by ... any person who believes that he is or is likely to be damaged by the use of any such 
trade dress infringement. ${ }^{145}$ The Court noted in Two Pesos that there was no reason to apply to trade dress analysis requirements that differ from those generally applicable to trademark infringement suits. The Court held that the trade dress of a Mexican food restaurant, consisting of architectural and interior design elements, was protected by the Lanham Act. ${ }^{146}$

The Court held that the defendant, Two Pesos, infringed on Taco Cabana's trade dress by adopting a motif very similar to that described as plaintiff Taco Cabana's trade dress. The Court's holding rested in part on the presumed procompetitive purpose of the Lanham Act. According to the Court,

[p]rotection of trade dress, no less than of trademarks, serves the Act's purpose to secure to the owner of the mark the goodwill of his business and to protect the ability of consumers to distinguish among competing producers. National protection of trademarks is desirable, Congress concluded, because trademarks foster competition and the maintenance of quality by securing to the producer the benefits of good reputation. ${ }^{147}$

Thus, the Court emphatically endorsed the view that trademarks are pro-competitive. From this point of view, the Court had no difficulty in expanding the boundaries of trademark protection to vaguely defined trade dress uses. ${ }^{148}$ The Court's willingness to protect a restaurant's motif on the ground that such protection is pro-competitive stands in stark contrast to the FTC's attack in the 1970 s on the registered trademark ReaLemon on the antitrust grounds that protection of that mark for lemon juice was anticompetitive. ${ }^{149}$

Prior to Two Pesos, trade dress protection under Section 43(a) of the Lanham Act had become "one of the most important weapons in the continuing effort by businesses to distinguish their products from those of their competitors

false description or representation.

15 U.S.C. § 1125 (1994).

145. See, e.g., Original Appalachian Artworks, Inc. v. Toy Loft, Inc., 684 F.2d 821, 830-32 (11th Cir. 1982); Sun-Fun Prods., Inc. v. Suntan Research \& Dev., Inc., 656 F.2d 186, 192 (5th Cir. 1981).

146. Plaintiff Taco Cabana described its trade dress as

a festive eating atmosphere having interior dining and patio areas decorated with artifacts, bright colors, paintings and murals. The patio includes interior and exterior areas with the interior patio capable of being sealed off from the outside patio by overhead garage doors. The stepped exterior of the building is a festive and vivid color scheme using top border paint and neon stripes. Bright awnings and umbrellas continue the theme.

Two Pesos, 505 U.S. at 765.

147. Park 'N Fly, 469 U.S. at 198 (citing S. REP. No. 79-1333, at 3-5 (1946)).

148. While the Supreme Court has indicated a willingness to expand trade dress and trademark protection, it has hesitated to expressly adopt an analogy between intellectual property rights and ownership of ordinary property. The Court has avoided an overly conceptual or formalistic treatment of patents, trademarks, and copyright as "property." In Dowling v. United States, 473 U.S. 207 (1985), the Court refused to hold that the National Stolen Property Act applied to the interstate transportation of "bootleg" phonorecords. The Court held that the rights of a copyright holder are "distinct" from the rights of owners of other kinds of property. Id. at 217. The Court avoided the easy analogy between intellectual property and ordinary property. "Thus, the property rights of the copyright holder have a character distinct from the possessory interest of the owner of simple 'goods, wares, [or] merchandise,' for the copyright holder's dominion is subjected to precisely defined limits." Id.

149. Two Pesos has been criticized as taking trademark protection into the realm of copyright and patents. See Melissa R. Gleiberman, Note, From Fast Cars to Fast Food: Overbroad Protection of Product Trade Dress under Section 43(a) of the Lanham Act, 45 STAN. L. REV. 2037 (1993). 
and to combat likelihood of confusion." ${ }^{50}$ The Two Pesos case followed the trade dress trend started by the Eighth Circuit's decision in Truck Equipment Service Co. v. Fruehauf Corp. ${ }^{151}$ In Fruehauf, the court held that protection against product imitation, parts of which were non-functional, ${ }^{152}$ "furthered the congressional policy of fostering fair competition and the policy of rewarding the creation of goodwill." 153 Thus, in applying traditional trademark protection policies in the area of trade dress, Fruehauf underscored the pro-competitive nature of trademarks. Two Pesos accepted this point of view.

The willingness of the Supreme Court to expand trademark protection under the Lanham Act was illustrated most recently by the Court's 1995 opinion in Qualitex Co. v. Jacobson Products Co., Inc. ${ }^{154}$ In Qualitex, the Court held that the Lanham Act permitted the registration of a trademark that consisted of the use of a color alone. The Court reinstated judgment for the plaintiff in its infringement claim against a competitor that had used a similar shade of greengold on dry cleaning press pads. The plaintiff had used the same shade of color on its pads since the 1950s and obtained trademark registration for the color on press pads in 1991. The Court held that dicta in its pre-Lanham Act cases against use of color alone as a trademark need not be followed because the Lanham Act "liberalized the common law" to dispense with technicalities. ${ }^{155}$ More significantly, the Court assessed whether allowing color alone as a trademark was inconsistent with "the basic objectives of trademark law."156 In doing so, the Court openly embraced the competitive value of trademarks generally. The Court concluded that the "source-distinguishing ability of a mark" permits it to serve two basic purposes: (1) makes purchasing decisions by potential customer easier by assuring the customer that the item with the mark is the item "that he or she liked (or disliked) in the past," and (2) assures a producer that it "will reap the financial, reputation-related rewards associated with a desirable product."157 The result, the Court concluded, was that trademark law "encourage[s] the production of quality products."158

Implicit in the Supreme Court's opinion in Qualitex is the acceptance of the Chicago School analysis of the competitive benefits of trademarks. The Court cited with approval the influential articles by leaders of the Chicago School that emphasized the pro-competitive benefits of the use of trademarks. ${ }^{159}$ In short, by accepting the Chicago School analysis of the competitive benefits of

150. 1 Jerome Gilson, Trademark Protection and Practice $\$ 7.02[7]$, at 7-68.21 (1995).

151. 536 F.2d 1210 (8th Cir.), cert. denied, 429 U.S. 861 (1976).

152. See supra text accompanying notes $114-24$ for an explanation of the functionality doctrine.

153. 1 GILSON, supra note $150, \S 7.02$ [7], at 7-68.22.

154. 115 S. Ct. 1300 (1995).

155. Id. at 1307.

156. Id. at 1303 .

157. Id.

158. Id. (quoting 1 MCCARTHY supra note $6, \S 2.01[(2)]$, at 2-3).

159. Qualitex, 115 S. Ct. at 1303-04 (citing Landes \& Posner, The Economics of Trademark Law, supra note 127, at 271-72; Landes \& Posner, Trademark Law: An Economic Perspective, supra note 127 , at 290. 
trademarks, the Court was more willing to expand trademark protection to include a mere color as a trademark. ${ }^{160}$

Thus, after years of silence on trademark issues, the Supreme Court's relative activism during the past decade has sent a strong signal to the lower federal courts that trademark protection should be broadly enforced. ${ }^{161}$ More important than merely the holdings in these recent Supreme Court cases is the Court's open embrace of the Chicago School economics justification for trademarks. Just as in antitrust law, Chicago School economic theories have provided the unifying basis for reconciling divergent legal doctrines.

\section{Legislative Expansion of Protection for Trademarks: The Revival of Trademarks as Property Rights}

As traditional trademark law is expanding gradually in the courts on a caseby-case basis, the underlying trends in trademark law are even more apparent in the statutory expansion of trademark law. The tension between competition and protection has been decisively resolved in favor of trademark protection in two important statutory enactments: the Trademark Law Revision Act of 1988 and the Federal Trademark Dilution Act of 1995. In both statutes, a shift in favor of greater protection, even perhaps a trend back toward a formalistic "property rights" approach, can be observed. In both instances, trademarks are treated more as property rights entitled to absolute protection. By analogizing trademarks to "property," it becomes easier to reason deductively that trademarks should be endowed with all kinds of additional protections. The new federal anti-dilution statute would appear to be an example of analogizing trademarks to "property." 162 Thus, after the attack on trademarks by legal

160. The Court in Qualitex recognized the potential for anticompetitive effects if a "color scarcity" problem arises. But the Court held that the trademark doctrine of "functionality" would be available to prevent "anticompetitive consequences" in that event. "The functionality doctrine thus protects competitors against a disadvantage (unrelated to recognition or reputation) that trademark protection might otherwise impose, namely their inability reasonably to replicate important non-reputation-related product features." Qualitex, $115 \mathrm{~S}$. Ct. at 1306.

161. The lower federal courts have not been deaf to these signals from the Supreme Court. Compare Prudential Ins. Co. v. Gibraltar Fin. Corp., 694 F.2d 1150, 1153 (9th Cir. 1982), cert. denied, 463 U.S. 1208 (1983) ("For policy reasons, this circuit has expressed a preference to read the Lanham Act narrowly .... To read the Act more broadly invites anticompetitive and irrational market behavior.") with Kohler Co. v. Moen Inc., 12 F.3d 632, 643-44 (7th Cir. 1993) ("Innovation in product design and marketing for the purpose of enhancing producer identity reduces the cost to consumers of informing themselves about the product source so that they can either continue purchasing the products from particular producers or avoid the products from those producers altogether.") and Sunbeam Products, Inc. v. West Bend Co., 39 U.S.P.Q.2d 1545, 1554 (S.D. Miss. 1996) ("However, the issue of competition in this case must be tempered when one attempts to compete unfairly.").

162. However, this legislative development is not necessarily typical of the reasoning adopted by the courts in expanding other areas of trademark protection. Most modern courts do not apply a conception of trademarks as "property" in a formalistic manner to decide specific issues in trademark law. Even though trademarks are loosely included as "intellectual property," most courts appreciate that the limited form of exclusive right conferred by trademark protection is qualitatively different from the type of absolute right to exclusion characteristic of other forms of property, particularly real and personal property. This distinction has been recognized in much of the case law. See 1 MCCARTHY supra note $6, \S 2.06$. 
realists and antitrust enforcers during the mid-twentieth century, it would appear that we have seen in the last decade something of a legislatively mandated return to the formalism that resulted in greater trademark protection in the late nineteenth century and early twentieth century. In short, we have come full circle. ${ }^{163}$

1. Trademark Law Revision Act of 1988. Congress significantly expanded the scope of trademark protection by passage of the Trademark Law Revision Act of $1988,{ }^{164}$ which amended the Lanham Act. Although the Revision Act left much of the Lanham Act unchanged, it made some procedural changes involving trademark registration that resulted in a significant substantive expansion of trademark rights.

The Revision Act eliminated the requirement that a trademark applicant must wait to file for a mark until common law rights have been established through use. The Lanham Act had followed the common law by requiring use of a trademark prior to making a trademark application with the Patent and Trademark Office. But the U.S. "use-first" system put U.S. companies at a disadvantage to the "registration-first" systems used in other countries, which give foreign competitors advantages because of reciprocal registration rights. ${ }^{165}$ Trademark owners wanted protection before doing "trial runs," when a trademark has been provisionally selected and is subject to being copied before final registration. American trademark owners strongly favored the Revision Act's rejection of a use-first system. ${ }^{166}$

Although the American use-first system was almost unique internationally, it was consistent with the prior common law approach to trademark protection. Under the Lanham Act of 1946, marks that were never used could not be properly registered with the Patent Trademark Office ("PTO"). ${ }^{167}$ This

163. For a modern criticism of the pejorative use of the label of "formalism," and an argument in favor of formalism as a rule-bound method of decisionmaking, see Frederick Schauer, Formalism, 97 YALE L. J. 509 (1988). Judge Posner contends that his economic theory of the common law embraces aspects of both legal realism and legal formalism.

It is realist because the concepts which provide the major premises for common law reasoning ... could be, and no doubt would be ... altered by the judges in response to changing perceptions of public policy. ... Once the basic premises are chosen on realist grounds ...., deduction can proceed without violating realist norms ... . The modern exemplar of formalism in common law is the positive economic analysis of that law which Professor Landis and I and others have expounded.

Posner, supra note 125 , at $185-86$ (but also arguing that formalism and realism have no application to statutory and constitutional law). See generally Page, supra note 126, at $42-70$ (concluding that in antitrust cases the Supreme Court has adopted a "legal process jurisprudence" in response to the realist critique by the Chicago School of Warren era decisions).

164. Pub. L. No. 100-667, 102 Stat. 3935 (codified in scattered sections of 15 U.S.C. (1994)).

165. See United States Trademark Association ("USTA"), Trademark Review Commission, Report and Recommendations to USTA President and Board of Directors, 77 TRADEMARK REP. 375, 392-93 (1987) [hereinafter Report of the Trademark Review Commission], reprinted in USTA, THE TRADEMARK LAW REVISION ACT OF 1988, at 75 (1989).

166. Id.

167. 15 U.S.C. $\$ 1051$ (1994) (requiring trademark applicant to state "the date of applicant's first use of the mark"). 
requirement was consistent with the general approach of the Lanham Act that the statute did not create trademark ownership but simply allowed registration of trademarks whose ownership had already been accomplished by a bona fide trade use. ${ }^{168}$ By requiring prior use of a mark before registration, the Lanham Act was consistent with common law trademark and unfair competition law of protecting business goodwill against misappropriation or "passing off" by unscrupulous competitors. Only trademarks in actual use could be the subject of a trademark infringement suit based on likelihood of confusion. In short, the Lanham Act of 1946 was consistent with common law themes of protecting goodwill and enforcing commercial morality.

The Revision Act, by allowing applications for registration of marks not yet in use, moves trademark protection closer to a "property" conception. Once anyone applies to register a trademark, even if it is not yet in use as the identifier of product source, it will be constructively "owned" by the applicant. ${ }^{169}$ The first to file has priority in the mark over even a competitor who first actually uses the mark as the identifying source of its products if that first use occurred after the other's application. ${ }^{170}$ In such a case, the first to apply may in effect take any business goodwill built up by a competitor who was the first to use the mark. The Revision Act does, however, attempt to mitigate any effort to register marks improperly by imposing an "intent-to-use" requirement on the applicant. In addition, the new law provides that registration by the PTO on the Principal Register will not actually occur until after an applicant for a mark has actually made a bona fide use in the trade. ${ }^{171}$ But the first "intentto-use" applicant still retains substantial rights.

This expansion of the Lanham Act is arguably consistent with a "property rights" notion of trademark. Indeed, the Revision Act has been criticized as inconsistent with economic theories that support trademark use. ${ }^{172}$ The argument is that by allowing rights for an applicant in marks that are not merely inventive or fanciful, competitors might be placed at some disadvantage in choosing more desirable marks. ${ }^{173}$ Thus, Congress has gone beyond both the common law and a pure Chicago-School economics justification for trademarks by passage of the Revision Act.

168. Under both the common law and the Lanham Act, trademark rights were obtained by adoption and use in commerce. See, e.g., Hydro-Dynamics, Inc. v. George Putnam \& Co., 811 F.2d 1470, 1472 (Fed. Cir. 1987); Law Societe Anonyme des Parfums Le Galion v. Jean Patou, Inc., 495 F.2d 1265, 1271 (2d Cir. 1974).

169. 15 U.S.C. $\S 1057$ (c) (1994) (providing in pertinent part that "the filing of the application to register such mark shall constitute constructive use of the mark, conferring a right of priority, nationwide in effect, on or in connection with the goods or services").

170. See Warnervision Entertainment, Inc. v. Empire of Carolina, Inc., 101 F.3d 259 (2d Cir. 1996).

171. 15 U.S.C. § 1051 (1994).

172. Stephen L. Carter, The Trouble with Trademark, 99 YALE L.J. 759 (1990). But other "law and economics" adherents have taken the position that trademark rights should be viewed as property rights. See Easterbrook, supra note 125, at 112 ("[A] right to exclude in intellectual property is not different in principle from the right to exclude in physical property."); Meiners \& Staaf, supra note 127 , at 912 (arguing that intellectual property is like any other exclusive private property right).

173. Carter, supra note 172. 
2. Federal Trademark Dilution Act of 1995. Nowhere is the law of trademarks more dramatically evolving than with respect to the anti-dilution amendment to the Lanham Act, Section 43(c)(1), the Federal Trademark Dilution Act of $1995 .{ }^{174}$ The federal dilution statute is designed to protect "famous" marks against unauthorized use in situations where trademark infringement does not exist. ${ }^{175}$ Some states had already enacted anti-dilution cases during the past several decades. Unlike traditional trademark infringement cases, state law dilution lawsuits have not required proof of a likelihood of consumer confusion between products. In such cases, there is little danger of a competitor stealing customers by passing off its goods as another's. Thus, for instance, use of the name "Spa'am" for a wild boar Muppet may be actionable even though "Spa'am" the Muppet is not a competitor of SPAM, and there is no risk that consumers will confuse "Spa'am" the Muppet with SPAM the food product. ${ }^{176}$ The new Federal Dilution Act expressly provides that dilution may occur "regardless of the presence or absence of (1) competition between the owner of the famous mark and other parties, or (2) likelihood of confusion, mistake, or deception." 177

Dilution is grounded on the idea that a trademark can lose its "ability ... to clearly and unmistakably distinguish one source" through unauthorized use. ${ }^{178}$ Dilution laws protect against either the "blurring" of a trademark's product identification or the "tarnishment" of the affirmative association a trademark comes to convey. "[D]ilution by blurring may occur where the defendant uses or modifies the plaintiff's trademark to identify the defendant's goods and services, raising the possibility that the mark will lose its ability to serve as a unique identifier of the plaintiff's product." 179 On the other hand, a trademark may be tarnished if it is "linked to products of shoddy quality or is portrayed in an unwholesome or unsavory context." 180 The new Federal

174. 15 U.S.C.A. $\S \S 1125(c)(1)$, (1127) (Supp. I 1996).

175. "The owner of a famous mark shall be entitled ... to an injunction against another person's commercial use in commerce of a mark or trade name, if such use begins after the mark has become famous and causes dilution of the distinctive quality of the mark." Id. $\$ 1125(\mathrm{c})(1)$.

176. See Hormel Foods Corp. v. Jim Henson Prods., Inc., 73 F.3d 497 (2d Cir. 1996) (suit arising under New York dilution statute, holding no dilution on the facts).

177. 15 U.S.C. $\& 1127$ (Supp. I 1996); see Ringling Bros.-Barnum \& Bailey, Combined Shows, Inc. v. Utah Division of Travel Dev., 935 F. Supp. 763 (E.D. Va. 1996) (claiming that "The Greatest Snow on Earth" on Utah license plates diluted "The Greatest Show on Earth" for the circus).

178. 3 MCCARTHY, supra note $6, \S 24.13[1]$, at 24-106.

179. Deere \& Co. v. MTD Prods., Inc., 41 F.3d 39, 43 (2d Cir. 1994). Dilution is a "gradual whittling away of a firm's distinctive trademark or name." Allied Maintenance Corp. v. Allied Mechanical Trades, Inc., 369 N.E.2d 1162, 1166 (N.Y. 1977).

180. Deere, 41 F.3d at 43. Most state-law dilution cases dealing with parody involve tarnishment of the mark. See, e.g., Anheuser-Busch, Inc. v. Balducci Publications, 28 F.3d 769 (8th Cir. 1994), cert. denied, 115 S. Ct. 903 (1995) (Michelob Oily joke ad); Dallas Cowboy Cheerleaders, Inc. v. Pussycat Cinema, Ltd., 604 F.2d 200 (2d Cir. 1979) ("Debbie Does Dallas" pornographic film). The new Dilution Act does not cover such "noncommercial use of a mark" as parody. Dr. Seuss Enterprises, L.P. v. Penguin Books USA, Inc., 924 F. Supp. 1559, 1573-74 (S.D. Cal. 1996). 
Dilution Act prohibits dilution under both the "blurring" and "tarnishment" theories. ${ }^{181}$

Anti-dilution laws derive from the concept that trademarks are property rights. ${ }^{182}$ Their value can be diminished by unauthorized use even in the absence of likelihood of consumer confusion over competing goods. The trademark bar actively championed passage of anti-dilution statutes to protect trademarks as "property rights." 183 The enactment of the federal legislation was hailed by trademark holders as a "significant step forward in protecting famous trademarks through the recognition that the presentation of a trademark's uniqueness or singularity is a valuable property right deserving of protection." 184 But the anti-dilution statute goes far beyond the traditional and Chicago School justifications for trademark protection. Like the formalist view of trademarks in the early twentieth century, ${ }^{185}$ once a trademark is treated as "property," broad rules of protection follow through simple deduction. ${ }^{186}$ This formalistic application of the property concept in trademark law was what so offended the legal realists. ${ }^{187}$

\section{Cyberspace and Beyond}

In the 1990s, trademark practitioners confront the problems of the use of trademarks in the computer age. The personal computer revolution, including widespread use of the Internet, presents trademark law with a new context in

181. Dr. Seuss, 924 F. Supp. at 1573; Clinique Laboratories Inc. v. DEP Corp. d/b/a Basique Labs, Inc., No. 96 Civ. 7045 (SAS), 1996 U.S. Dist. LEXIS 15003 (S.D.N.Y. Oct. 10, 1996).

182. See Rudolf Callman, Unfair Competition Without Competition? The Importance of the Property Concept in the Law of Trade-Marks, 95 U. PA. L. REV. 443, 453-54, 466 (1947) ("The protection that can be granted to a trade-mark on the basis of a property right is most extensive . . . Therefore, a trade-mark owner can be protected against injury from those who are not competitors only when the trade-mark is held to be an exclusive right.").

183. See, e.g., Report of the Trademark Review Commission, supra note 165, at 454. "[T]he positive associations that comprise a brand-a brand's equity - can rise to the level of a property right entitled separately to protection irrespective of confusion or the existence of a dilution statute." Jerre B. Swann \& Theodore H. Davis, Jr., Dilution, an Idea Whose Time Has Gone; Brand Equity As Protectable Property, the New/Old Paradigm, 1 J. INTELL. PROP. L. 219, 220, 238 (1994) (arguing that the purposes of the anti-dilution statute could be accomplished judicially through recognition of trademarks as property and trademark infringement as a form of trespass on property).

184. Mary Ann Alford, International Trademark Assoc., Exec. V.P., and V.P. and Assistant Gen. Counsel of Reebok Int'l Ltd. (quoted in INTA BuLLETIN 6 (Jan. 1996)).

185. See Frank I. Schecter, The Rational Basis of Trademark Protection, 40 HARV. L. REV. 813, 817 18 (1927).

186. Anti-dilution laws arguably implicate several important interests. Judge Kozinski has suggested that the legality of use of trademarks on non-competing goods can be assessed by examining moral claims, utilitarian considerations, risk of negative goodwill, and the public's interest in free and open communication, "four different kinds of interests implicated by giving trademark owners a more extensive property right in their marks." Alex Kozinski, Trademarks Unplugged, 68 N.Y.U. L. REV. 960, 977 (1993).

187. See Ralph S. Brown, Jr., Advertising and the Public Interest: Legal Protection of Trade Symbols, 57 YALE L.J. 1165, 1191-94 (1948); Felix Cohen, Transcendental Nonsense and the Functional Approach, 35 COL. L. REV. 809, 814 (1935). 
which to apply traditional doctrine-cyberspace. ${ }^{188}$ Commentators have written about the problematic effect on the enforcement of trademarks caused by the mass usage of electronic mail, on-line services, and the Internet. ${ }^{189}$ Among the trademark issues that have arisen on the Internet is whether the Internet domain names (for example, http://www.internic.net/) that serve as addresses on the Internet can be the subject of trademark infringement actions $^{190}$ and whether domain names may be registered as trademarks. ${ }^{191}$ Courts have held that the new Federal Trademark Dilution Act of 1995 may provide a basis for protecting famous marks that are used by others as domain names on the Internet. ${ }^{192}$ Another difficult issue is whether the courts will afford trade dress protection for computer screen displays. ${ }^{193}$ A more conventional problem is the unauthorized use of a trademark on a worldwide web site or a computer bulletin board service's online display. ${ }^{194}$ As this technology progresses, the tension between access and protection of trademarks will become more acute. ${ }^{195}$

188. "Cyberspace" refers to the "space" in which networked computer systems communicate. The term was first used by author William Gibson in his novel Neuromancer.

189. See Kenneth S. Dueker, Trademark Law Lost in Cyberspace: Trademark Protection for Internet Addresses, 9 HARV. J. L. \& TECH. 483 (1996); Jessica R. Friedman, A Lawyer's Ramble Down the Information Super Highway, 64 FORDHAM L. REV. 730 (1995); Gary W. Hamilton, Trademarks on the Internet: Confusion, Collusion or Dilution?, 4 TEX. INTELL. PROP. L.J. 1 (1995).

190. See, e.g., MTV Networks, a Div. of Viacom Int'l, Inc. v. Curry, 867 F. Supp. 202 (S.D.N.Y. 1994) (suit by the TV network to prevent use of domain name "mtv.com." by a former employee). Every domain name must be unique, and is registered on a first-come, first-serve basis by the domain name registrar, Network Solutions, Inc. ("NSI") of the Internet Network Information Center ("InterNIC"). Since 1995, NSI has revised its rules to require a representation from new applicants that use of its domain name does not infringe any trademark, and NSI may suspend use of its Internet address if a trademark holder disputes ownership of the domain name. Dueker, supra note 189, at 497-507. NSI does not prescreen domain names to determine if the name is already a protected trademark.

191. The PTO has reportedly taken the position that domain names are registerable as trademarks if used as trademarks. See Special Bulletin: Registration of Internet Domain Names, in U.S. PTO, INT'L TRADEMARK AsS'N (1995).

192. Panavision Int'l, L.P. v. Toeppen, 945 F. Supp. 1296 (C.D. Cal. 1996) (enjoining non-competitor who had registered with NSI the domain name "panavision.com," diluting the Panavision trademark); Hasbro, Inc. v. Internet Entertainment Group, Ltd., 40 U.S.P.Q.2d 1479 (W.D. Wash. 1996); Intermatic Inc. v. Toeppen, 40 U.S.P.Q.2d 1412 (N.D. Ill. 1996).

193. See Rhoda L. Rudnick, Window Dressing: Trademark Protection for Computer Screen Displays and Software, 80 TRADEMARK REP. 382 (1990).

194. See Playboy Enters. v. Frena, 839 F. Supp. 1552 (M.D. Fla. 1993) (finding trademark infringement from a BBS display of photographs with Playboy's trademark); Sega Enters. v. MAPHIA, 857 F. Supp. 679 (N.D. Cal. 1994) (finding trademark infringement from use of the Sega name and logo by a computer BBS that allowed users to download unauthorized copies of Sega video games).

195. The computer revolution has presented an even greater challenge to copyright law practitioners. Computer software copyrightability law is still in its infancy. See Brown Bag Software v. Symantec Corp., 960 F.2d 1465 (9th Cir.), cert. denied, 506 U.S. 869 (1992); Computer Assocs. Int'l, Inc. v. Altai, Inc., 982 F.2d 693 (2d Cir. 1992); Whelan Assocs., Inc. v. Jaslow Dental Lab., Inc. 797 F.2d 1222 (3d Cir. 1986), cert. denied, 479 U.S. 1031 (1987); Lotus Dev. Corp. v. Borland Int'l, Inc., 799 F. Supp. 203 (D. Mass. 1992), rev'd, 49 F.3d 807 (1st Cir. 1995), aff'd, 116 S. Ct. 804 (1996); Lotus Dev. Corp. v. Paperback Software Int'l, 740 F. Supp. 37 (D. Mass. 1990). The copyrightability of the "look and feel" of software operating systems was the subject of an important copyright infringement case. Apple Computer, Inc. v. Microsoft Corp., 821 F. Supp. 616 (N.D. Cal. 1993), aff'd, 35 F.3d 1435 (9th Cir. 1994), cert. denied, 115 S. Ct. 1176 (1995); Apple Computer, Inc. v. Microsoft Corp., 799 F. Supp. 1006 (N.D. Cal. 1992), order clarified, 1993 WL 207982, affd, 35 F.3d 1435 (9th Cir. 1994), cert. denied, 115 S. Ct. 
The conflict of property rights and competition in cyberspace has already resulted in a revitalization of antitrust law in this context. While issues of trademark enforcement were not directly involved, the Department of Justice investigation and subsequent settlement with Microsoft Corporation ${ }^{196}$ highlight the attention that antitrust enforcement agencies will bring to bear on the computer industry. ${ }^{197}$

IV

\section{CONCLUSION}

The history of trademark law can best be understood against the backdrop of larger trends in legal philosophy, theory, and doctrine. The perceived tension in trademark law between protecting entitlements and encouraging competition through free access to marks has long animated trademark law and doctrine. This tension is most dramatically illustrated by the interplay between trademark law and the antitrust laws. As the political currents became more conservative after the 1960s and 1970s, the pendulum swung back to greater protection for trademarks and less expansive application of antitrust law in the trademark context. Influenced by the Chicago School, current antitrust and economic theory holds that trademarks are pro-competitive, which the courts and enforcement agencies have largely accepted as resolving any conflict in trademark law between competition and protection. In the legislative arena, there has even been a revival of the view that trademark rights are "property rights." Whether the trend toward greater protection of trademarks will continue into the computer age in the next century remains to be seen.

1176 (1995); see Nicolas P. Terry, GUI Wars: The Windows Litigation and the Continuing Decline of "Look and Feel," 47 ARK. L. REV. 93 (1994). In rejecting Apple's claims of copyright infringement with respect to the "look and feel" of the Macintosh computer interface, the court was sensitive to competitive market effects: "One need not profess to know for sure where should lie the line between expression and idea, between protection and competition to sense with confidence that this [Apple's claims of copyright] would afford too much protection and yield too little competition." Apple Computer, 799 F. Supp. at 1025-26. See generally Frederick R. Warren-Bolton et al., Copyright Protection of Software Can Make Economic Sense, 12 COMPUTER LAW. 10 (1995).

196. The district judge's initial rejection of the proposed consent decree was reversed on appeal. United States v. Microsoft Corp., 159 F.R.D. 318 (D.D.C.), rev'd, 56 F.3d 1448 (D.C. Cir.), on remand, 1995 WL 505998 (D.D.C. 1995); see Kenneth C. Baseman et al., Microsoft Plays Hardball: the Use of Exclusionary Pricing and Technical Incompatibility to Maintain Monopoly Power in Markets for Operating System Software, 40 ANTITRUST BULL. 265 (1995). Chicago School economists have been critical of the government's case against Microsoft. See John E. Lopatka \& William H. Page, Microsoft, Monopolization, and Network Externalities: Some Uses and Abuses of Economic Theory in Antitrust Decision Making, 40 ANTITRUST BULL. 317 (1995).

197. See Melissa Hamilton, Software Tying Arrangements Under the Antitrust Laws: A More Flexible Approach, 71 DENV. U. L. REV. 607 (1994) (arguing that intellectual property protection is procompetitive); Stewart A. Pomerantz, A Lawyer's Ramble Down the Information Super Highway: Recent Antitrust Developments and a Selective Antitrust Perspective of the Information Superhighway, 64 FordHAM L. REV. 808, 809-12, (1995). 
